\section{Blomstedt i Gewandhaus}

\author{
Gewandhauskapelmesteren \\ fortæller om Bach, Bruckner, \\ Mahler, Sibelius, Nielsen \\ og en hjemløs \\ til \\ John Fellow
}

4 nhver dansker, der interesserer sig for klassisk musik, har hørt om Gewandhaus i Leipzig. Det var dér, Mendelssohn i forrige århundrede for alvor udviklede den moderne koncertinstitution. Det var dér, Niels W. Gade fik uropført sin første symfoni og med ét slag blev verdensberømt, efter at man i København havde afvist at spille symfonien. Gewandhaus var dér, hvor Gade selv kom til at dirigere, hvor han bl.a. uropførte Mendelssohns violinkoncert, og hvor han ved Mendelssohns død efterfulgte denne som Gewandhauskapellmeister, og måske havde Gade slet ikke făet den store betydning for udviklingen af musiklivet i København, for Musikforeningen og Musikkonservatoriet, som han i dag især huskes for, hvis ikke Preussen i oprørsåret 1848 havde blandet sig i slesvigholstenernes opstand mod styret i København og derved tvunget Gade til at rejse hjem, hvis han ikke ville have et skær af landsforræder hængende ved sig.

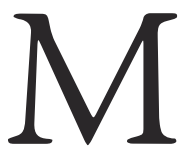
usik og Leipzig har i århundreder været synonyme begreber, ikke kun på grund af Gewandhaus, men også i kraft afThomaskirken, hvor Bach virkede fra 1723 til sin død i 1750, og til hvis gudstjenester han komponerede hovedparten af sine kantater og passioner. I dag er Leipzig en by på knap en halv million indbyggere, men med et musikliv, som nordiske byer ikke engang kan drømme om. Thomaskirken ligger, hvor den altid har ligget, og trods krige og politiske omskiftelser er det berømte Thomanerkor stadig garant for en ubrudt Bach-tradition.

Gewandhausorkestret har til huse i sin tredje koncertsal, Neues Gewandhaus, som ligger ti minutters gang fra Thomaskirken på Augustusplatz, indtil for ti år siden Karl Marx Platz, med front mod operahuset på den modsatte side af pladsen. Både operahuset og Neues Gewandhaus er bygget $\mathrm{i}$ DDR-tiden, og ikke mindst Neues Gewandhaus, som blev taget i brug i 1981, er et vellykket stykke moderne arkitektur, som ikke synes tynget af det daværende politiske system og dets æstetik. Leipzig er gammel handels- og messeby. I kommunisttiden var byen udstillingsvindue for den østtyske industri, og Neues Gewandhaus, der med sine 1900 pladser i dag akustisk er en af verdens bedste koncertsale, har tydeligvis profiteret af byens karakter af port til verden udenfor. Udover disse traditionsrige institutioner har også Mitteldeutscher Rundfunk med eget symfoniorkester og et af Tysklands bedste kor, MDR-koret, hjemme i Leipzig.

\section{ewandhaus fik sit navn i 1781, da det da 38 år gamle koncertselskab, der var finansieret af byens}

købmænd, flyttede ind i klædehandlernes messehus, det såkaldte Gewandhaus, i en sal med plads til 500 tilhørere. Det var her Mendelssohn og Gade optrådte. I 1884 byggede byen en ny stor koncertsal med plads til 1500 tilhørere og, som i det nyeste Neues Gewandhaus, med tilhørende kammermusiksal. Også dette andet berømte Gewandhaus, der blev ødelagt af brandbomber i 1944, kom til at spille en rolle i dansk musikliv. Herhen styrede Carl Nielsen 


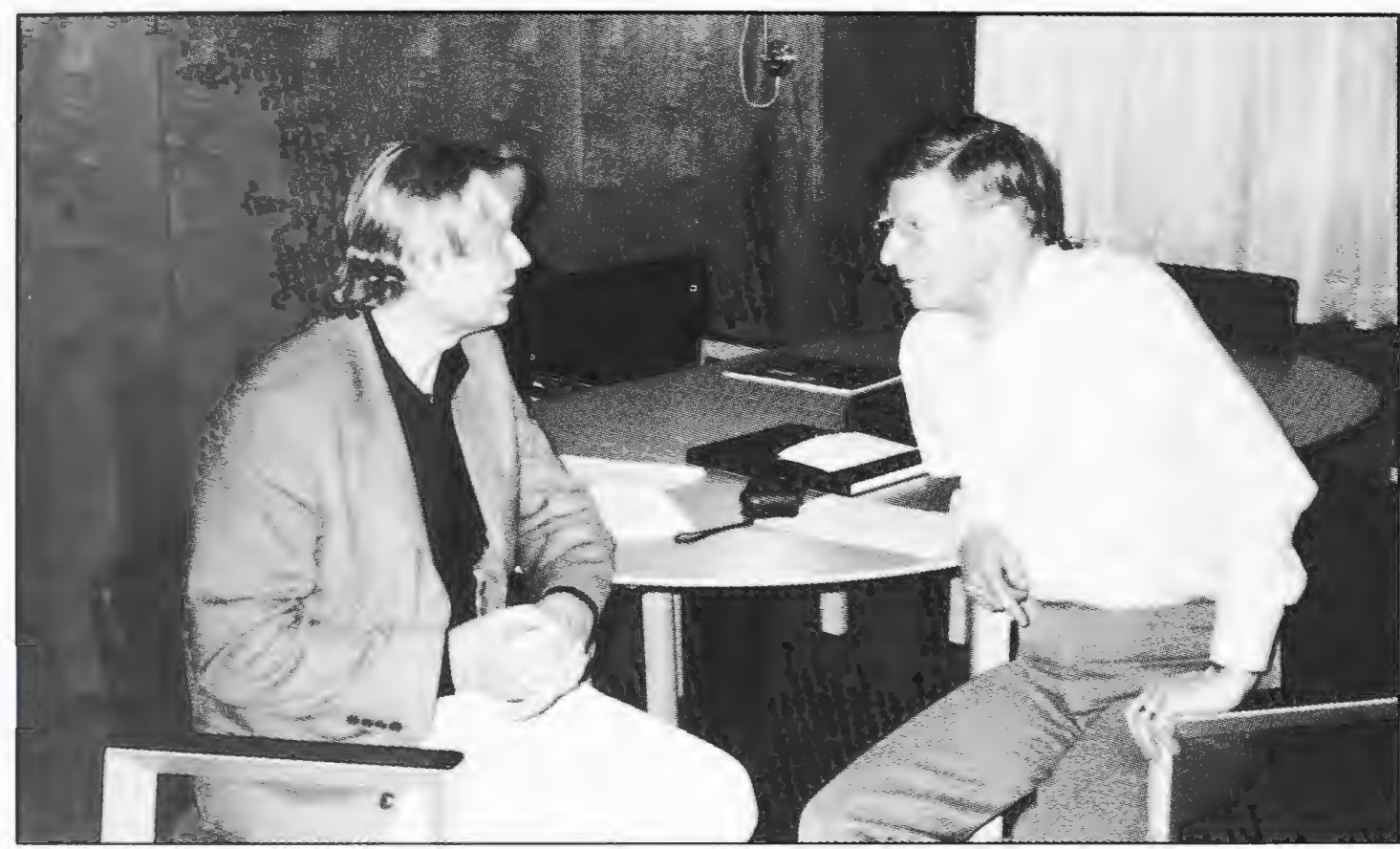

John Fellow'(til venstre) i samtale med Herbert Blomstedt.

allerede på sin forste udlandsrejse i 189()-91, her horte han den beromte violinist Joachim pille, og her afleverede han til den davarende (jewandhauskapellmeister Carl Reinecke et brev, som han havde med fra Crade, der imidlertid var dod i mellemtiden. Reinecke brast i gråd, da han så Gades brev: Ach, mein verstorbener Freund! - har (arl Nielsen senere fortalt. Mange år senere, i oktober 1927, var Carl Nielsen igen i Ieipzig, og da var han selv hovedperson, idet Wilhelm Furtwängler og

Gewandhausorkestret opforte hans 5 . symfoni og dermed leverede en af de storste succeser, som (arl Nielsens musik oplevede i hans levetid. ()g å påanden måde havde Carl Nielsen ojnene rettet mod l eipzig, der også var europaisk hovedby for musikforlag. Flere gange forsogte han at forbedre sin okonomi og at trixnge igennem uden for Skandinavien ved at skifte til tysk forlag, og således udkom hans Sinfonia espansiva i 191.3 på Leipzig-forlaget C..F. Kahnt

- Nachfolger og klaversuiten op. 45 og den sidste strygekvartet på C.F. Peters forlag i Leipzig i 1923.

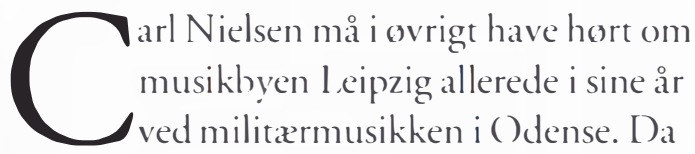
modtog han nemlig samtidig undervisning af dirigenten for byens musikforenings orkester, klokkeren og kordegnen ved byens domkirke, Carl Larsen, der som provinsmusiker var lidt ud over det saedvanlige, og som i sin ungdom havde opholdt sig i læengere tid i L eipzig i de samme år, som også en anden nordisk musiker, som fik betydning for Carl Nielsen, Johan Svendsen, studerede der, altså i årene 186,3-67.

Nu er der igen grode i Nielsen i L eipzig. Den 72-årige (nu 74-årige) svenske dirigent Herbert Blomstedt, som fra 1968 til 1978 var chef for Radiosymfoniorkestret, som dengang indspillede alle Carl Nielsens symfonier, koncerter og mindre orkesterstykker, og som i slutningen af firserne endnu engang indspillede symfonierne i San 
Francisco på plademærket Decca, blev i 1998 ny Gewandhauskapellmeister, og i den langsigtede programlægning har han placeret Carl Nielsens hovedværker side om side med hele serier af fortidens største symfonikere, Beethoven, Brahms, Bruckner, Mahler, Sibelius. Hvert år skal den Nielsen, som de københavnske aviser i århundredets begyndelse hængte ud, fordi nogle af hans tilhængere havde sammenlignet ham med Mozart og Beethoven, nu i et af verdens førende musikhuse dele en koncert med den Beethoven, som i hans ungdom var en sådan musikalsk grundoplevelse, at han som ældre kunne skrive, at "hans Aand favnede mig tidligt og saa stærkt, at jeg var ved at skrige"! Også i kammermusiksalen i Gewandhaus optræder Nielsen med flere af sine værker.

Der synes at være god grund til, at vi fra dansk side påskønner Blomstedts indsats for Nielsen, som næppe nogen anden dirigent i de sidste årtier har spillet så meget uden for Skandinavien, og hvad er da mere nærliggende end i det mindste at besøge Blomstedt og Leipzig for at fortælle ham om Carl Nielsen-forskningen i Danmark, for at forære ham et eksemplar af den nylig udkomne udgave af Carl Nielsens skrifter, Carl Nielsen til sin samtid, I-III, og et af Carl Nielsen Udgavens ny partiturer, den 5. symfoni, som står på programmet i Gewandhaus til næste efterår.

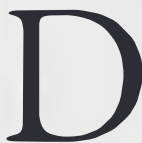
a H.C. Andersen i 1840 passerede Leipzig, gik han uanmeldt til Gewandhaus og afbrød Mendelssohn midt i prøverne på Beethovens 7. symfoni. Mendelssohn blev ganske vist irriteret over at blive forstyrret $\mathrm{i}$ arbejdet, men da det gik op for ham, at det var den kendte Andersen, han havde foran sig, endte det alligevel i omfavnelser og strålende ansigter. Sådan foregår det, når man hedder Andersen, og året ikke er 1999.

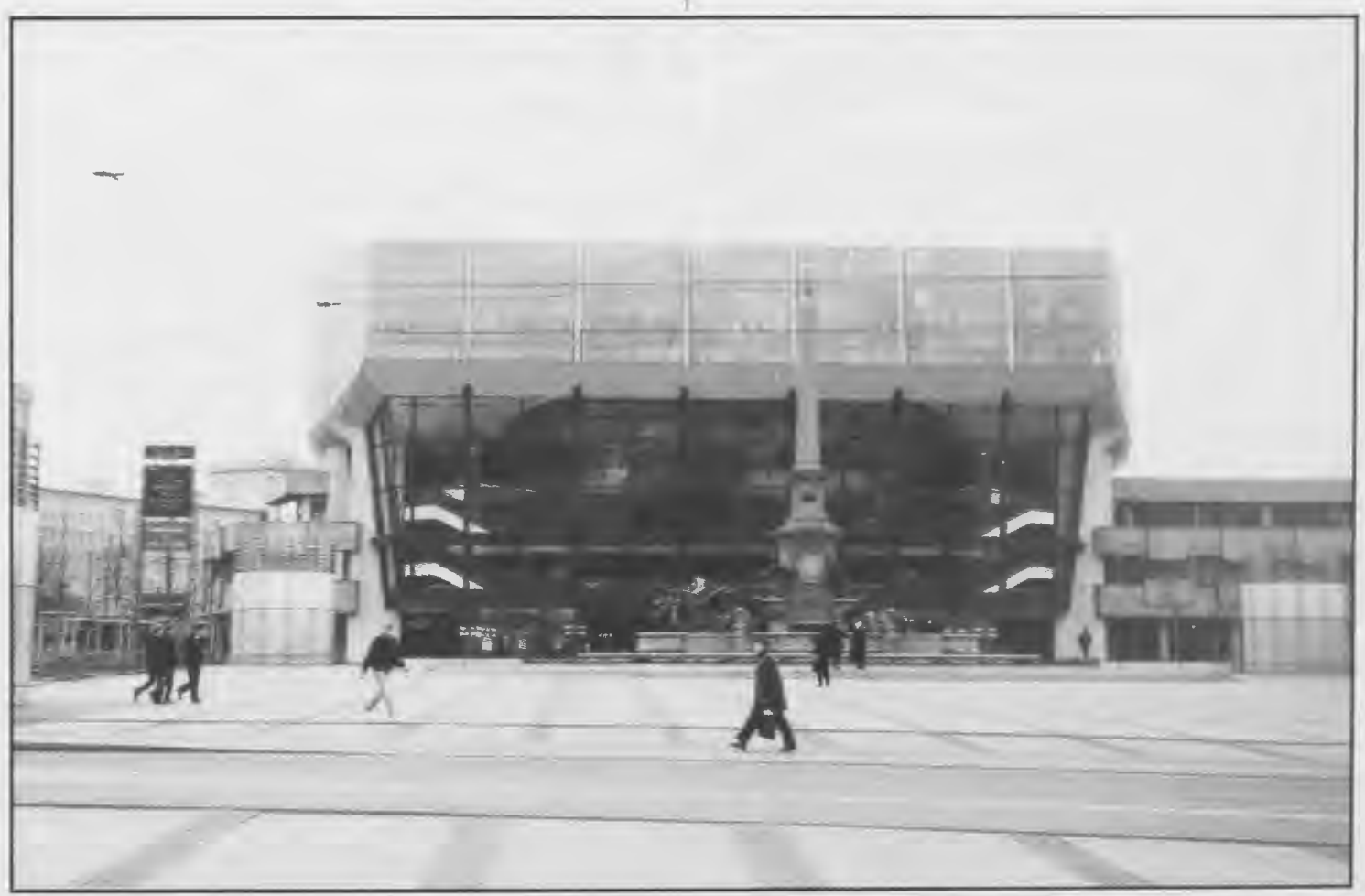

Neues Gewandhaus, det tredje Gewandhaus, som blev taget i brug i 1981. 
I dag er kommunikationsmidlerne udviklet, alting går hurtigere, afstanden er blevet mindre, og til at styre forbindelserne imellem landenes sammensatte musikliv, har disse oprettet hele organisationer. I Danmark har vi Dansk Musik Informations Center, hvis projektkoordinator Jens Rossel jeg orienterede om Blomstedts Nielsen-projekt i Leipzig. Så skete der noget. E-mails fløj frem og tilbageimellem København og Leipzig og rundt i København, og også de gammeldags telefoner glødede. Dagen før Gewandhausorkestret og Blomstedt skulle opføre Beethovens Pastorale og Nielsens Det uudslukkelige, den anden og tredje december 1999, var aftalen i hus, og jeg kunne begive mig af sted i et så gammeldags befordringsmiddel som tog og såmænd være næsten lige så længe eller kort tid om turen til Leipzig, som Carl Nielsens var det på sin tid. Gyldendal, som har udgivet Carl Nielsen til sin samtid, og Carl Nielsen og Anne Marie-Carl Nielsens Legat havde givet hver en skærv til det gode formål, Wilhelm Hansen havde givet et partitur, Gewandhaus havde givet hotel og billetter i koncertsalen, og jeg selv supplerede med min arbejdskraft og min lyst til at høre koncerten og til at møde den dirigent, hvis fortolkninger af Nielsen og alle de andre store har glædet og inspireret mig i så mange år.

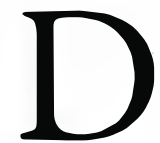
er var udsolgt hus begge dage, og jeg var ikke i tvivl om, at ikke kun Beethoven, men også Nielsen gik hjem. Omkring mig nærmest emmede det af medleven, da vi nåede til sidstesatsen med dens paukeduel, og fremkaldelserne opgav jeg at holde styr på. Hagen Kunze, der anmeldte koncerten i Leipziger Volkszeitung, og som jeg trafi koncert- pausen, var heller ikke i tvivl om, som han

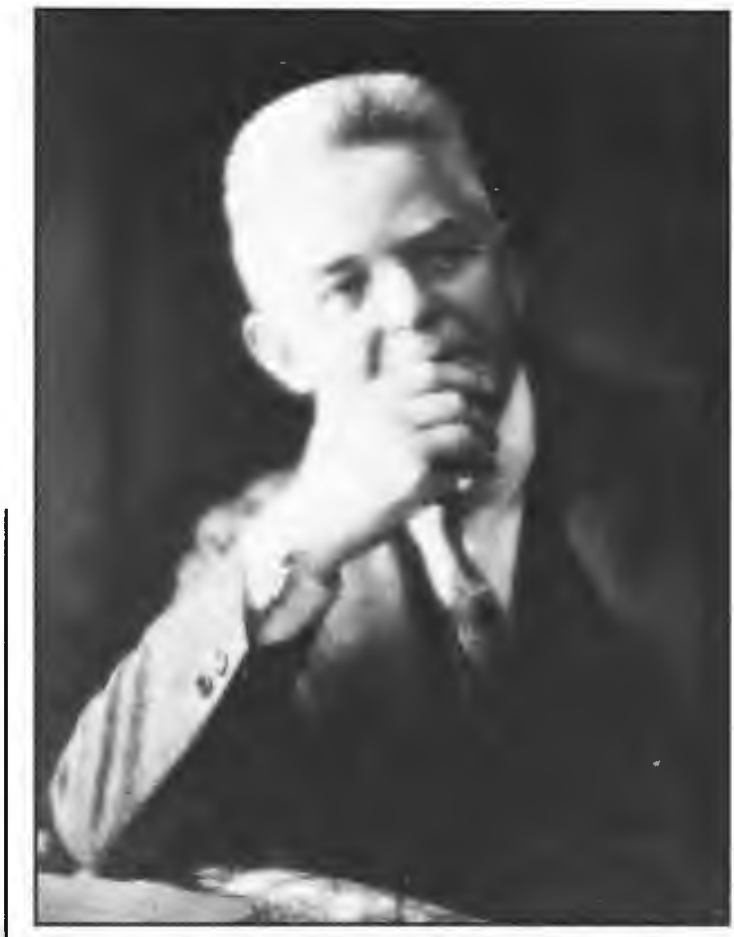

Carl Nielsen (1865-1931).( Det Kongelige Bibliotek, Billedsamlingen).

skrev, at Nielsen ikke hører hjemme i den nationale skuffe, men at hans symfonier tværtimod lever op til universale krav. Der er endda et gab imellem hans værkers originalitet og deres stilling i det internationale repertoire, et gab, som Herbert Blomstedt i mange år har forsøgt at lukke, og skønt hans indspilning af symfonierne i San Francisco har reference-karakter, så bød opførelsen med Gewandhausorkestret ikke desto mindre på overraskelser. Det sørgede f.eks. den i Leipzig genindførte tyske orkesteropstilling for: I sammenligning med cdindspilningen, klang symfonien her, som den var tænkt. For ligesom Mahlers symfonier behøver også Nielsens de delte violiner (dvs. 1. og 2. violinerne på hver sin side af dirigenten, til forskel fra den amerikanske orkesteropstilling, hvor 2. violinerne gemmer sig bag 1. violinerne til venstre for dirigenten, og som i dette århundrede har bredt sig 
til alverdens symfoniorkestre). Igen og igen føres de to grupper fra hinanden. Lige så vigtig som samklangen er de melodiske liniers forskellighed. Som snebolde kastede de to grupper motiver til hinanden, greb hinandens tanker og førte dem videre, hed det $\mathrm{i}$ anmeldelsen.

$\mathrm{J}$ eg skulle møde Blomstedt umiddelbart efter dette drama. Han tog imod mig, stadig i kjole, i den åbne dør til ewandhauskapelmesterens kontor, som er et smukt og enkelt rum, ikke meget større end et førstebibliotekarkontor på Det Kongelige Bibliotek, udstyret med et skrivebord, et mindre konferencebord og et flygel, og med de samme mørke træpaneler med grønligt skær, som også præger koncertsalen. Aldrig så snart var vore hænder mødtes, før han talte dansk. Jeg takkede ham for aftenens Pastorale og Det uudslukkelige, to natursymfonier fra hver sin tidsalder. Jeg havde ganske vist på forhånd gennem Blomstedts sekretær bedt om, at interviewet måtte foregå på skandinavisk, men havde forestillet mig, at det var naturligt at tale tysk $\mathrm{i}$ begyndelsen.

- Hier kommt mehr Nielsen! Sagde jeg, stillede tasken midt på gulvet og begyndte at lægge bøger og partitur op på bordet.

I løbet af sekunder løb samtalen på svensk og dansk. Emnet var jo givet. Jeg fortalte kort, hvad det var, jeg medbragte, og snart var det mig, der blev interviewet. Det var tydeligvis en tilfredsstillelse for Carl Nielsen-fortolkeren, at høre at der omsider var gang i Carl Nielsen-forskningen i Danmark. Han var i forvejen velorienteret $\mathrm{i}$ den eksisterende Carl Nielsen-litteratur, vidste at der måtte være forskel på det partitur, han var vant til at bruge til 5 . symfoni og det ny kildekritiske, og han glædede sig til at studere det:

- Man skal ikke ændre i instrumentationen, som Tuxen har gjort, man skal bevare Nielsens oprindelige farver. Balanceproblemer kan klares med dynamiske ændringer.

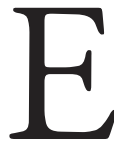

fter den store indsats i San Francisco, havde han lagt Nielsen på hylden $\mathrm{i}$ håb om at andre ville begynde at spille ham. Hvis Nielsen skulle have den plads i repertoiret, som han fortjente, var det nødvendigt. Det var i virkeligheden af begejstring for Carl Nielsen, jeg var tilbageholdende, fortæller Blomstedt, ikke fordi, jeg havde fået nok. Men det skete bare ikke. Da han for nylig igen spillede den 4. i San Francisco, havde de ikke spillet den, siden han sidst spillede den med dem for mere end ti år siden. Ingen andre havde pillet ved fortolkningen: den kom ud, som den var blevet stoppet ind i sin tid! - Den ikke helt unge dirigent griner drenget og imponeret. Og begejstringen var stor hos publikum, som må have dyrket cd'erne i de forløbne år. Jeg fortæller, at et vigtigt motiv for mig til at bruge adskillige år på at samle og udgive Carl Nielsens skrifter, har været, at jeg ønsker at påvirke opfattelsen af Carl Nielsen, som jeg har oplevet som både mangelfuld og fordrejet. Næsten som et svar herpå taler Blomstedt om sit eget missionsinstinkt: Her er noget absolut fantastisk, som vi ikke kender, og man brænder af lyst til at vise andre, hvad det er! Men det har også en risiko. Det som man efterhånden kender så godt, føler man meget intensivt for, og når man så ikke umiddelbart får den respons, som man håber på, så bliver man utrolig skuffet. Det må man tage med i sine beregninger.

Vi er forlængst blevet sat over hjørne ved konferencebordet, og det går 
langsomt op for mig, at vi allerede er langt inde i en samtale, der kan løbe af sig selv, jeg ved ikke hvor længe, at tiden går, og at vi næppe har hele natten for os. Næste dag skal dirigent og orkester i Frankfurt spille det samme program. Jeg må tage mig sammen og forsøge at styre samtalen, hvis jeg skal have det interview med herfra, som jeg har planlagt. Jeg lægger en lille båndoptager frem på bordet imellem os, idet jeg gør opmærksom på, at vi har aftalt at lave et interview. Det bliver signal til, at vi bliver dus.

\section{Sachsen som musikland}

$$
\text { - I ti ior var du cheffor }
$$

Staatskapelle i Dresden, og efter 10 arr i San Francisco og tre år i Hamburg er du nu (jew'andhauskapellmeister i Leipzig. Hvad er det, der gor, at du og musiklivet i Sachsen uanset styret - holder si meget af hinanden?

- Det har mange aspekter. Jeg kom til Dresden på et tidspunkt, da det var meget svære tider i Østtyskland. Det var lige efter Pragforåret. Russerne var marcheret ind i Prag, og østtyske soldater var også med til at slå opstanden, som de kaldte det, ned. De tjekkiske musikere, som arbejdede i Østtyskland, kunne naturligvis ikke acceptere, at deres hjemland blev invaderet af soldater fra det land, som de arbejdede i, og de rejste øjeblikkeligt hjem. Det gjorde Vaclav Neumann, som var chef her i Leipzig, og det gjorde Martin Turnovsky, som var chef for operaen i Dresden. Den første årsag, til at jeg blev indbudt til at gæstespille i Dresden, var, at man behøvede dirigenter til at fylde det vakuum, som var opstået.

Det udviklede sig. Det tog lang tid. Jeg havde meget svært ved at bestemme mig: Det var et elendigt land, men en dejlig by og et fantastisk musikliv og et herligt - orkester. Den relation som jeg fik til kapellet i
Dresden og til publikum i Dresden var naturligvis af musikalsk natur, men den var også en personlig reaktion, også fra publikums side. For dem blev jeg et lille lys af håb i en situation, hvor de var håbløst lukket inde og landet isoleret. Selv kunne de ikke rejse ud, og de vidste, at Østtyskland havde et meget dårligt image i verden som helhed. På de vilkår levede de, men nu oplevede de, at her kom en musiker fra den vestlige verden, som af egen fri vilje accepterede at komme hertil og mere eller mindre dele deres skæbne. Det var som om, de fik et lufthul, så de kunne begynde at ånde igen. Jeg blev en slags symbol for dem for den fri verden, som man vidste fandtes derude. For dem var det som et uudtalt løfte om, at den verden ville de komme i kontakt med igen på et eller andet tidspunkt.

Det er baggrunden. Jeg mærkede jo deres taknemmelighed. Publikum i Dresden og Leipzig er helt unik, også i sammenligning med resten af Tyskland.

$$
\text { - Ja, det har jeg også allerede }
$$

bemarket, og også Carl Nielsen talte, da han $i$ 1927 havde varet $i$ Leipzig og hort Furtwängler opfore sin 5. symfoni, om "den store andagt, denne glade ved musik", som han oplevede hos publikum endda over for ny og anderledes musik.

Sagde han det også! - Folk bliver siddende tilbage på deres pladser til orkestret går ud! De har en utrolig Ausdauer, og som musiker får man det indtryk, at musikken synker i dybet.

$$
\text { - Er der en, der taler, tysser man pa }
$$
vedkommende. Hvis man forsoger at tysse $i$ Kobenhavn, bliver man selv upopular, man skal endelig ikke tage det for hojtideligt!

$$
\text { - Ja, publikum i Sachsen er noget }
$$

specielt. - Det var en musikalsk meget lykkelig tid for mig i Dresden. Jeg mærker det, når jeg kommer tilbage som gæst, det er 
altid den samme historie: Vi kan ikke begynde at spille, uden at de fortsætter med at klappe, og jeg må vende mig om og tysse dem ned. På den måde siger de: Velkommen, tak skal De have, fordi De var her i så mange år! Godt at se Dem igen! - Det er meget bevægende.

Man hører og ser på Blomstedt, at det også er bevægende at fortælle om det. Han skifter toneleje for at konkludere:

- Det var lidt af baggrunden for den relation.

- Men hvordan er det så gået til, at Sachsen er blevet et så fantastisk musikområde?

- Det er der mange årsager til. En af dem er, at Sachsen ligger så nær ved Böhmen. På mange måder er böhmerne de mest musikalske mennesker i Europa. Musik - når jeg taler om musik, mener jeg klassisk musik, ikke pop og rock osv. - musik er böhmernes måde at leve og udtrykke sig på, og i Sachsen er det lidt det samme. De slaviske rester findes overalt her. Man ser det på stednavnene. Leipzig er et slavisk ord, stedet, hvor der vokser lindetræer, og mange navne i omegnen er slaviske: Schkeuditz hedder lufthavnen, og Wiederitz, der er -itz, -itz overalt. Det slaviske er altså én årsag, en anden er, at Sachsen i mange år havde den lykke at have konger, som var utrolig interesseret i kunst og musik. August den Stærke, som på Bachs tid residerede i Dresden og gjorde byen til et fænomenalt kunstcentrum, er det mest kendte eksempel.

- Og netop musikken var vel så også fredet i den kommunistiske tid? Musikken var den kunstart, der blev slaet mindst $i$ stykker?

- Ja, man kunne ikke ramme den så let. Med musik kunne man ikke gøre så meget propaganda som med teater f.eks.

- Med musik kunne man fortsatte med at sige sandheden, uden at den blev

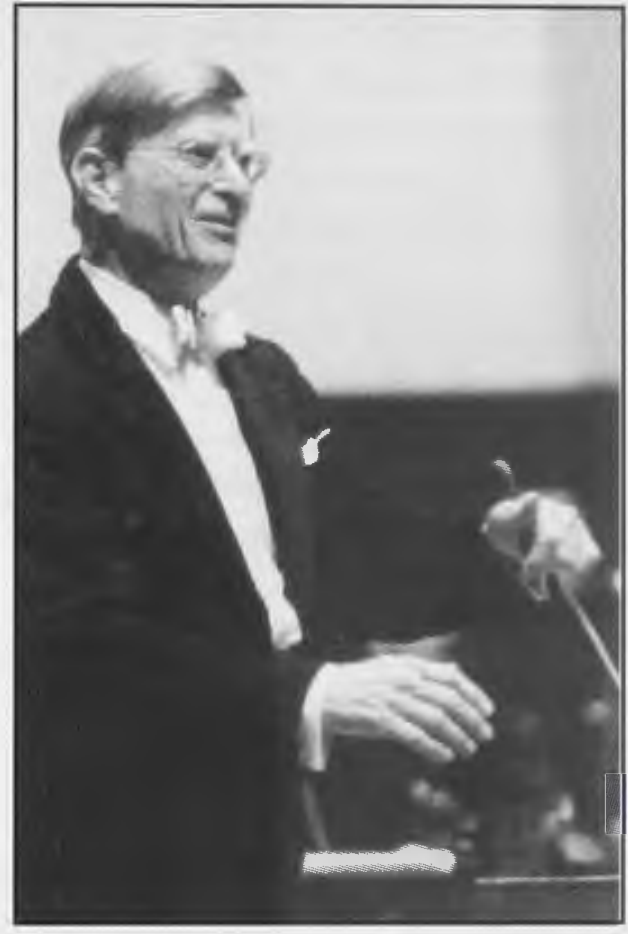

Herbert Blomstedt.

\section{forstået af de forkerte!}

$$
\text { - Ja! - De gjorde nok forsøg på }
$$

dét også, men det var så isoleret. Regien til Fidelio, som jeg dirigerede på operaen i Dresden, havde f. eks. en klar marxistisk tendens, som irriterede mig forfærdeligt. Jeg var på nippet til at nægte min medvirken, men det var ikke nemt som chef, og desuden måtte jeg erkende, at på det tidspunkt fandtes der så mange marxister også i den vestlige verden. Sverige var lige så socialistisk som Østtyskland, det var bare ikke et diktatur, men i filosofien! -

Musikken var stort set fredet for politiske indgreb. Jeg føler mig meget på bølgelængde med menneskene her, med deres kærlighed til musikken og med deres livsalvor, trods alle disse år med nazisme og kommunisme og nu de sidste ti år med grænseløs materialisme, som man godt kan forstå efter isolationen. Der er noget særligt her, som ikke findes i de fleste andre tyske byer. 
- Kan det så bevares her? I vest ser den granselose materialisme ikke just forbigäende ud!

- Jeg tror det. Die Bachpflege her, som man kan sige meget, også kritisk, om - de har jo stået stille i 50 år - men blot det faktum, at her musicerer man Bach hver eneste uge $\mathrm{i}$ både Thomaskirken og andre kirker. Gewandhausorkestret er det eneste orkester, som spiller Bach i tjeneste hver uge, året rundt!

- Naturligvis ikke tubaspillere og harper! siger Blomstedt, pludseligt med en høj smittende latter og et glimt i øjnene, som hurtigt forvandles til saglighed igen.

- Men alle, som Bach har skrevet for, de gør det, og selv om der ikke er flere udøvende og bekendende kristne her, det er der måske også, så betyder det, at der er en almindelig respekt, kærlighed til og forståelse for den kultur, som Bachs kultur repræsenterer, og som ikke findes de fleste andre steder. Folk går jo sjældent i kirke, slet ikke i Skandinavien, det ved du lige så godt som jeg, og heller ikke i Tyskland, det er ikke interessant og relevant for moderne mennesker, men Thomaskirken! Altid fuld! Altid Fuld! 2000 mennesker hver eneste gang! Det er naturligvis på grund af Bachs musik, som på den måde bliver en slags katalysator for evangeliet. Hvis Bach havde kunnet stå op af sin grav i dag, så tror jeg, han ville have sat pris på at opleve, at han har været og er en eksponent for det evangelium, som betød så meget for ham. Byen og menneskenes bevidsthed her er præget af dette forhold. Selv om de fleste kun kender det på afstand, og det kun er et lille ornament, så er det en del af deres liv.

- Jeg gatter på, at du selv har haft Bach som en meget vigtig del af din bagage altid, men du har vist ikke dirigeret så meget - Bach, det er jo ikke ham symfoniorkestrene spiller $i$ vor tid, så det er vel en udvidelse af dit repertoire, at du nu i Leipzig skal spille de store Bach-varker, passionerne, og h-mol-messen, som du i ourigt også skal spille $i$ Kobenhavn og Ribe til paske?

- Det er en tilbagekomst. Jeg spillede meget Bach med mit første orkester i Norrköping, det var jo et lille orkester, Bach var ideelt. Men efterhånden som de orkestre, jeg arbejdede med, blev større, så blev også mit repertoire udvidet i den retning. Både i Oslo, som var den første station efter Norrköping, og i København, hvor vi tilmed havde to orkestre (Radiosymfoniorkestret og Radiounderholdningsorkestret) og kunne spille Gurrelieder og Mahlers 8. osv. uden problemer, trådte barokken lidt i baggrunden, og da jeg begyndte i Dresden blev Richard Strauss et must. Det er den eneste grund til, at jeg har spillet mindre Bach i de senere år. Det er musik, som interesserer mig kolossalt.

\section{Carl Nielsen - ude eller hjemme}

- Vi har allerede talt om Nielsen, men ham bliver vi ikke så let fardige med. Han blev engang spurgt, hvad det vigtigste var, når man dirigerede, og han svarede: At man ikke forstyrrer musikerne, når det går godt. Hvad ville du svare?

- Det indeholder en stor sandhed - især hvis man har musikere, som tager initiativ, og som har det i sig - men det han tilføjer er vigtigt: Når det går godt! En dirigent kan forårsage meget ondt, hvis han griber ind imod musikkens natur, og det sker alt for let, så Carl Nielsens svar indeholder en meget stor sandhed, men det siger også noget andet om Carl Nielsen: Han var efter de oplysninger, vi har, en meget dårlig dirigent, så han gjorde sikkert det bedste ved at gribe ind så lidt som muligt, blot hans personlighed var nok til at gøre musikerne 
topkoncentreret.

- Ja, meningerne var meget delt om Carl Nielsen som dirigent, og det hanger nappe kun sammen med hans dirigentevner, men ogsa med hans opfattelse af musikken. Han spillede med hurtigere tempi, holdt ikke af alt dette rubato spil, som de populare dirigenter dengang svalgede $i$.

- Han var en moderne dirigent! Men han siger et sted, at den tanke, som nogle har, at man kan studere direktion, er latterlig: Man kan ikke lære det. Det ligger der også en sandhed i, men det viser også, at han ville ikke have kunnet lære det!

Igen denne befriende latter.

- I dag har kunsten at dirigere mange flere aspekter, end den havde i 1931. I dag må man studere direktion, det er så kompliceret, orkesterapparatet er så kompliceret, men naturligvis har Carl Nielsen ret i, at der er momenter i direktionsaktiviteten, som må være medfødt, og har man ikke dem...

Døren går op. Blomstedts sekretær bryder ind og beder om, at han tager sin kjole af, da den skal pakkes ned til gæstespillet i Frankfurt i morgen. Han rejser sig og undskylder over for mig. Tre minutter efter er han tilbage i civil, og samtalen forsætter.

- Hvordan har
Gewandhausorkestret reageret på Nielsen sammenlignet med orkestret i San Francisco?

- Begge orkestre har reageret

fabelagtigt, men meget forskelligt.

Gewandhausorkestret er et vidunderligt orkester at musicere med. Det sidder dybt. På den første prøve spillede jeg symfonien straight through, uden at afbryde en eneste gang. De spillede naturligvis ikke perfekt, men de havde intet besvær med at følge tråden. Det imponerede mig, storartet at de kunne gøre det. Det er meget svær musik, ikke bare teknisk, også musikalsk er den svær, et nyt sprog. Man gør let dumme fejl, fordi der ikke kommer det, man tror. Rytmisk er der forskydninger, som man ikke venter sig. På mange måder lyder musikken så at sige normal, men lidt anderledes. Man ved ikke rigtig, hvor man er henne, er man hjemme eller ude!

Vi ler begge spontant: Nielsen, hjemme eller ude? Det er spørgsmålet!

- Så der er en vis forvirring, en indre forvirring, som musikerne naturligvis ikke artikulerer. Hvad er det her for noget? Det er de alt for professionelle til at sige, men de er åbne. Jeg synes, de har gjort det vældig godt, og deres indstilling er i det hele taget utrolig disciplineret. Og orkestret har kun spillet symfonien én gang før, med Paavo Berglund for 12 år siden.

\section{- Hvordan opfatter du Carl}

Nielsens placering i traditionen?

- Jeg kan ikke placere ham som et led i en kæde. Han er helt unik.

- Ogdet er ikke blot, fordi kaden er gået i stykker $i$ vort århundrede?

- Carl Nielsen har ikke haft den indflydelse på eftertiden, som man kunne have forventet sig, af to grunde: Dels er han født i et lille land, og da han døde i 1931, var han for ukendt til at andre komponister $\mathrm{i}$ den store verden kunne lade sig påvirke af ham og sige: Her har vi noget, vi kan spille videre på. Dels var hans musik for de radikale ikke tilstrækkeligt moderne, og for de traditionelle var den alt for moderne, den faldt mellem to stole. Han kunne ikke rangeres ind i Stravinsky-lejren, endnu mindre i Schönberg-lejren, og heller ikke i Richard Strauss-lejren. Han passede ikke ind nogen steder.

- Det er svart at finde noget senere at sammenligne Nielsen med, men med isar den sene Hindemith, som heller ikke er in $i$ 


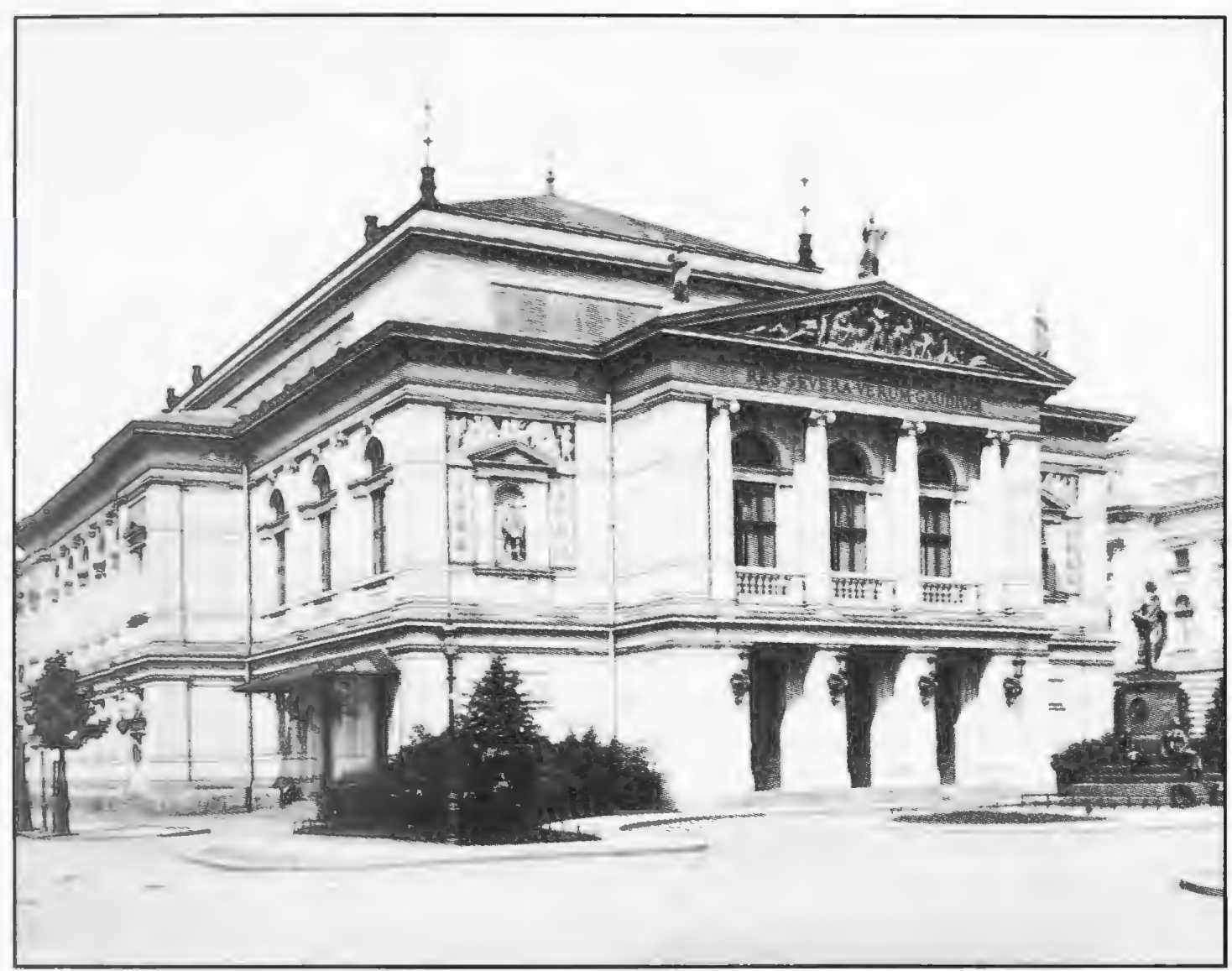

Det gamle Neues Geunandhaus fia 1884 blev bombet i 1944. Her horte Carl Nielsen musik pi sin forste udlandsrejse i 1890-91, og her oververede han i 1927 Furtüänglers opforelse af den femte symfoni. (Det Kongelige Bibliotek, Billedsamlingen).

dag, erder lisse fallestrak?

- Begge reagerede mod romantikken. Hindemith meget radikalt i sine unge ar i tyverne og begyndelsen af trediverne, mindre da han kom til Amerika og var blevet ældre og mere moden. Nielsen gjorde det på sin egen meget personlige måde, men som Hindemith orienterede sig mod barokiken, gjorde Nielsen det ogsai, men han gik et skridt længere tilbage, renæssancen spillede næsten en storre rolle for ham, takket være Knud Jeppesen og Palestrinaforskningen, som blomstrede i I)anmark.

- Carl Nielsen studerede Palestrina allerede i 1890 'erne!

- Ja, pá det punkt var han beslægtet med Brahms, som ogsà var historiker. Brahms var jo ikte musikvidenskabsmand i moderne betydning, han havde et stort bibliotek, han medvirkede som udgiver af nogle bind i den store Bach-udgave og i den store Schubertudgave, og han studerede netop meget renæssancemusik. Han var dirigent for et damekor i sine unge àr, og det har sat sig utrolige spor i hans kompositioner fra de tidligste korstykker til de allersidste. Alt dette er tydeligt til stede ogsä i Carl Nielsens musik. I den fjerde symfoni, som vi netop har spillet, var denne anden sats utankelig ... Blomstedt synger stilfærdigt fra allegrettoen ... hvis ikke senrenæssancen havde været der 


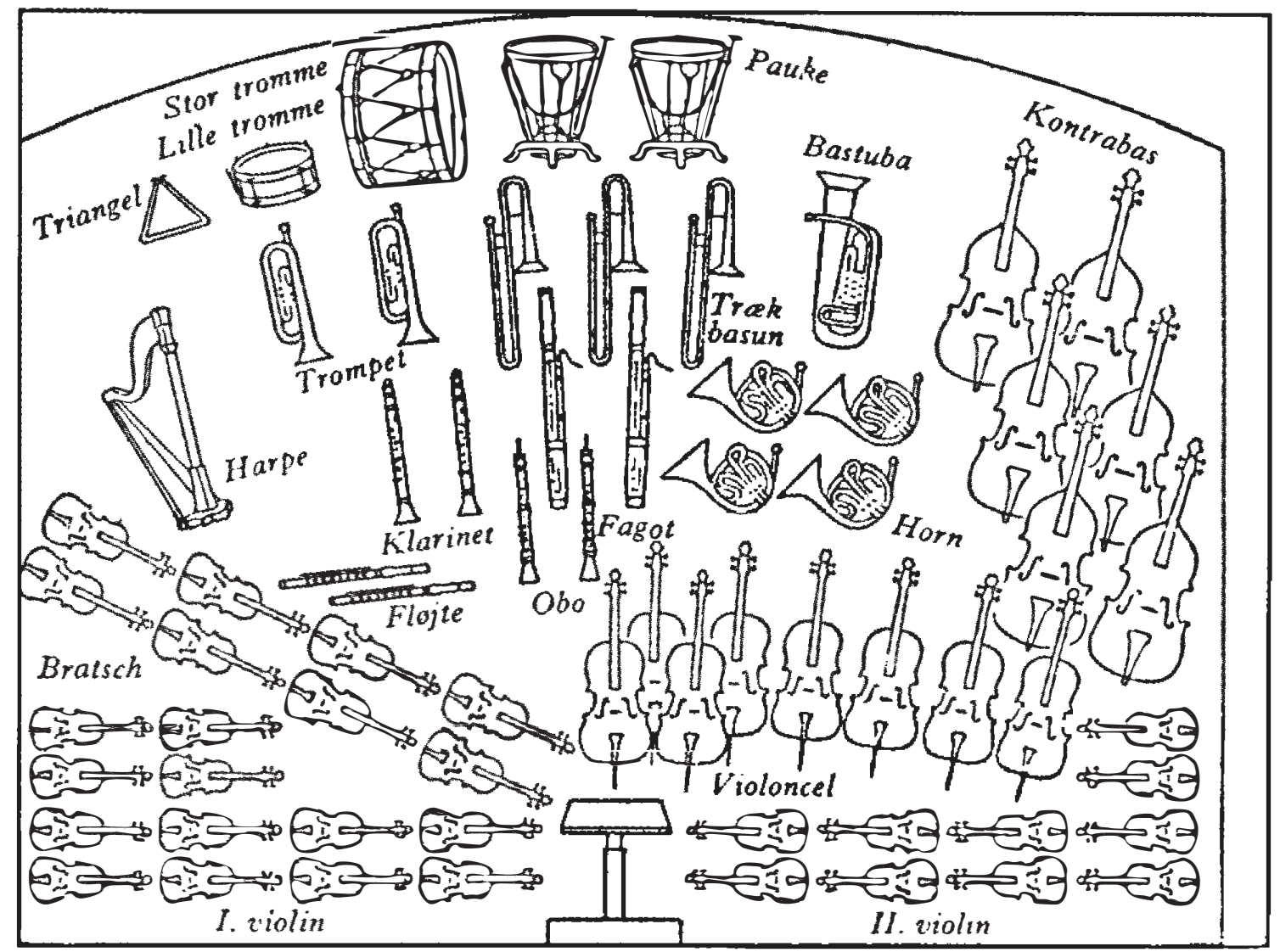

Den oprindelige europaiske orkesteropstilling.

med Hans Leo Hassler f.eks.

Jeg tror, at hvis Carl Nielsen har en fremtid som inspirator for andre komponister, så må det være nu. Han døde for tidligt og levede så at sige på et forkert tidspunkt til at få indflydelse på samtidige komponister. Det lokale er noget andet. I Skandinavien, hvor han var velkendt og en værdsat figur og havde mange beundrere ...

- Men trods alt alligevel ikke rigtig efterfolgere afformat? Man kan spore indflydelse hos Hilding Rosenberg, men alligevel mere fra Sibelius?

- Rosenberg er et specielt

tilfælde. Jeg mener nu, at der er mere Nielsen end Sibelius i Rosenberg. I visse værker kan man spore Sibelius, men Rosenberg er jo i høj grad en intellektuel musiker, mens Sibelius var en mere instinktiv musiker, utrolig klart tænkende med et fantastisk symfonisk instinkt, som ikke har noget med improvisation at gøre, men Carl Nielsens musik er arkitektonisk på en helt anden måde end Sibelius', og det tror jeg tiltalte Rosenbergs temperament meget. Mange satser i Rosenbergs symfoniske værker var utænkelige uden Carl Nielsen. - Anden sats af Sinfonia Grave er det svart at tonke på uden samtidig at tonke på Nielsens 5., og den er jo så god, at der alligevel er tale om mere end blot en efterligning.

- Ja. -

- Hvad betyder den ny orkesteropstilling med 1. og 2. violinerne på huer sin side af dirigenten? I virkeligheden er det jo den oprindelige, det var sådan også Carl Nielsen brugte det. 


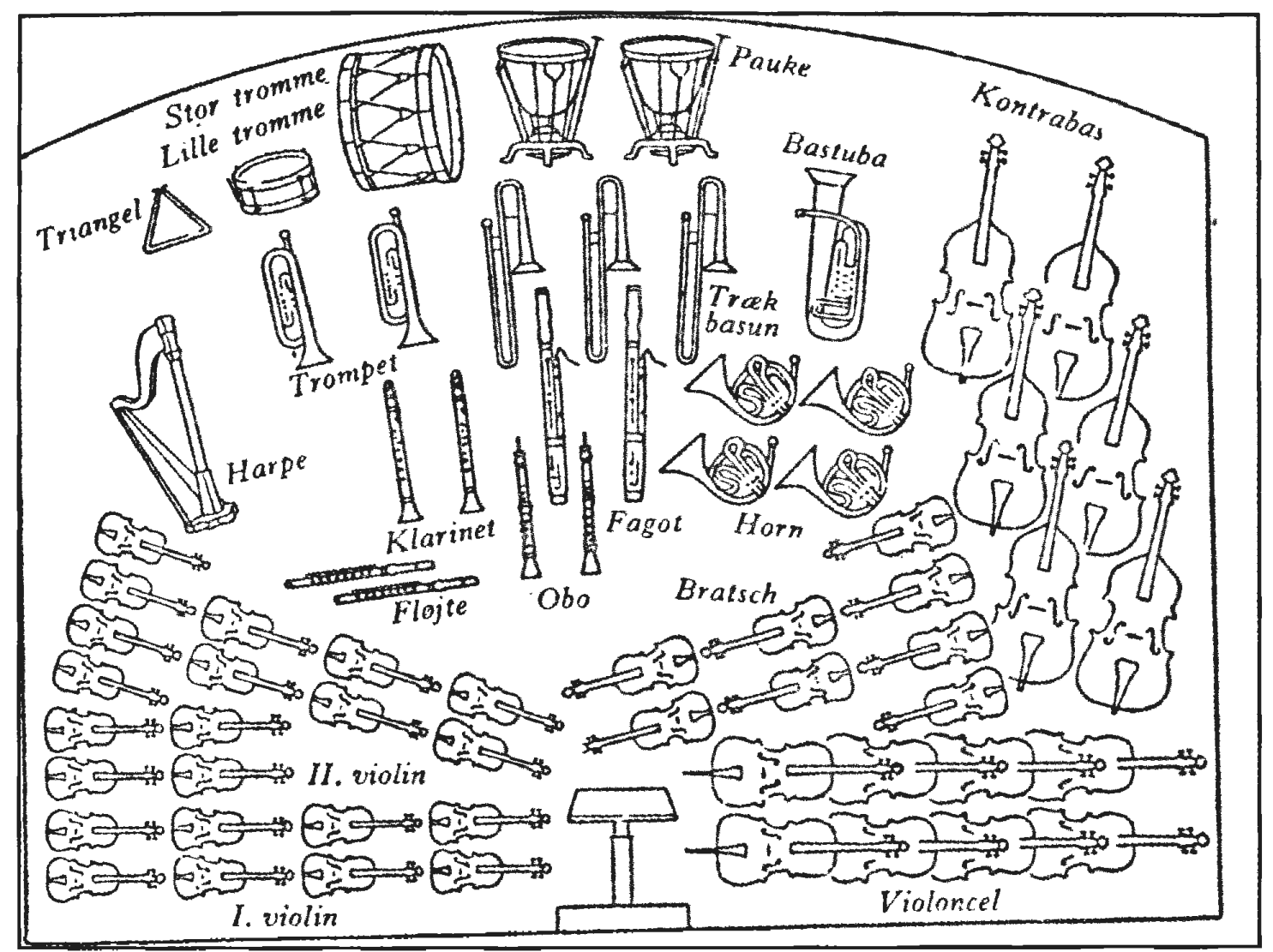

Den amerikanske orkesteropstilling.

- Sådan skal det være. Det har jeg vidst praktisk taget hele mit liv! Men jeg har ikke vovet det, for det er jo svært, i begyndelsen. Anden violinerne er blevet så vant til at sidde i skyggen af første violinerne og få en mægtig hjælp af dem rent rytmisk. Når de sidder isoleret på den højre side, som de også gjorde det i Carl Nielsnes eget orkester og egentlig i alle klassiske perioder, så er de nødt til at blive mere selvstændige og tage mere initiativ, og det er kun godt. Jeg har ikke konsekvent anvendt den opstilling i mere end fem år. Da jeg sluttede i San Francisco, tænkte jeg: Nu! nu! nu eller aldrig, nu må jeg vove det!

- Jeg ville gøre det i San Francisco allerede i 1992, men så skulle vi igennem en stor akustisk ombygning af vores sal, til 12 mill. dollar, med en dansk arkitekt, Laurence
Kierkegaard. Han er direkte efterkommer af Søren Kierkegaard ...

\section{- Er han det!}

- Kierkegaards bror! og når man ser ham, slår det en med det samme: Billedet af Kierkegaard! Der er han igen, det er den familie!

Latteren runger i Gewandhauskapelmesterens kontor. Af og til har vi kunnet høre latter inde fra sekretærkontoret, nu må det være dem, der kan høre os.

- Det er ganske fantastisk, fortsætter Blomstedt, man bliver så lykkelig, og han er sådan et dejligt menneske. Nå, det var altså ham, der styrede den her renovering, og den lykkedes $100 \%$, og så tænkte jeg, når vi nu flytter ind i salen, så laver vi den ny opstilling. Men så sagde orkestret noget, som også var forståeligt for mig: Nej, 
ikke nu. De ville gerne teste den ny akustik under de samme forhold som tidligere, og hvis vi flyttede om nu, kunne vi ikke vide, om det klingede anderledes, fordi vi sad anderledes, eller det var, fordi salen var ny. Det var et gyldigt argument, og så løb det ud i sandet. En egentlig opposition imod det var der ikke. Så besluttede jeg, at ti år i San Francisco egentlig var nok, og jeg tænkte, at nu fortsætter vi, til jeg slutter her, men bagefter: Absolut!

- Det giver en anden totalklang, og man kan hore 2. violin-stemmen, når den adskiller sigfra 1. violinernes...

- Orkesterklangen bliver mere transparent, det giver en bedre dialogsituation, og det giver også violinerne en bedre klangbredde i salen. Når første og anden violinerne spiller unisont eller $\mathrm{i}$ oktaver, og de spiller en cantilene, så kommer den svævende fra hele podiets bredde.

Jeg spiller med den opstilling konsekvent nu, og det var ikke svært at overbevise orkestret om, at vi skulle ændre opstillingen. De har været utrolig loyale, for de kræver også at sidde sådan, når gæstedirigenterne kommer. Gewandhausorkestret har faktisk siddet sådan indtil ind i tresserne. Konwitschny (Franz Konwitschny, Gewandhauskapellmeister 1949-62) var den gamle skoles mand, og så længe han var her, sad man efter den gamle opstilling. Den amerikanske opstilling, hvor 2 . violinerne gemmer sig bag 1. violinerne, den har en ganske kort historie her, men menneskene vænner sig jo så hurtigt til alting, og så spørger man, hvorfor gør du det? Men nu har de opdaget det, og de fleste ved også hvorfor.

- Paukerne i Carl Nielsens fjerde symfoni skulle faktisk også stå på en sarlig made. Af anmeldelserne fra uropforelsen kan man se, at pauke nr. to faktisk stod foran

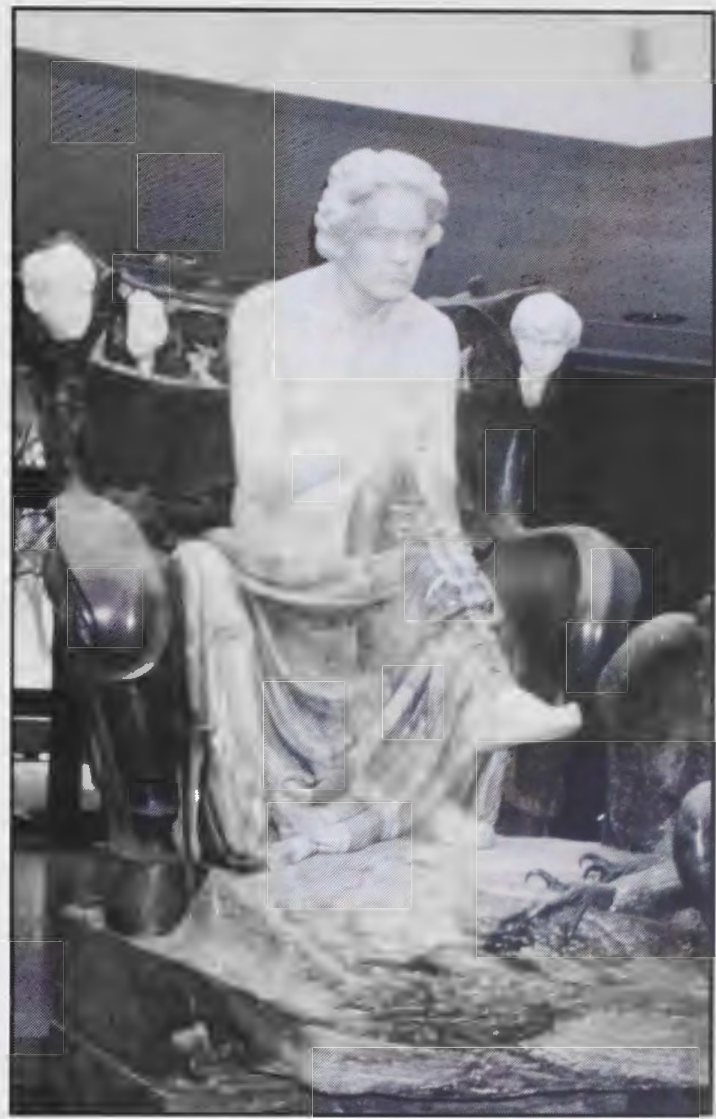

Max K'lingers beromte Beethovenstatue (1902) har $i$ dag sin plads $i$ Klingerfoyeren $i$ Gewandhaus.

violinerne, narmest publikum. Det er aldrig lykkedes mig at opleve symfonien på den måde, heller ikke i aften.

- Ja, det er sådan, han vil have det, det står i partituret. Jeg har ikke villet gøre det, fordi violinerne ikke er vant til at have pauker så nær ved sig, og de ville skade deres fine intonation, som er utrolig følsom. Messingblæserne er vant til paukerne, og de spiller selv en kraftig rolle. Det væsentlige er, at paukerne bliver stillet antifonisk op.

Virkningen fremkommer også, når paukerne er anbragt i de to bagerste hjørner. Det er også et pladsspørgsmål, vi har jo mange flere violiner, end Carl Nielsen havde, han havde sikkert aldrig 16/16, som vi spiller med. 
dromte sikkert om flere, og ved den nordiske musikfest $i$ Kobenhavn i 1919 slog man byens to symfoniorkestre sammen $i$ både Det undslukkelige og Sibelius'anden.

- Med hans massive blæserinstrumentation må det have været endnu vanskeligere at få en ordentlig balance med få strygere, men det var tidens vilkår. Liszt opførte Lohengrin her i Weimar Stadtteater med otte førstevioliner!

\section{- I Kobenhavn måtte man låne}

Det Kongelige Teaters pauker for at have pauker nok til den fjerde symfoni, og man kunne altså ikke opfore den på en dag, hvor der også blev spillet opera. Så lille en musikby var Kobenhavn på Carl Nielsens tid!

- Der er sket adskilligt siden da.

På sekretærkontoret kan de igen høre vores latter. en tredje, af symfonierne?

- Kommer der en ny indspilning,

- Det ser ikke ud til det. Grammofonbranchen er jo i en dyb depression. Jeg har med orkestret her lavet fem indspilninger for Decca, og tre er udkommet, Brahms' fjerde, Bruckners niende og Hindemiths Die Harmonie der Welt og Sinfonia Serena, de to andre, en Straussplade og en Mendelssohnplade, kommer ud, langsomt, firmaet eksisterer jo næsten ikke. Vi håber, at Decca igen kommer på den grønne gren, så vi kan begynde at lave indspilninger igen, men vi ved det ikke. For et par år siden så det specielt dårligt ud for Decca. skifte marke?

- Kunne det ikke komme på tale at

- Jeg har jo eksklusivkontrakt med Decca, men de har givet mig frie hænder og sagt, at jeg frit kan indspille med et hvilket som helst selskab. Jeg har ventet lidt, man skal jo ikke bare løbe sin vej. Har - man først etableret en kontakt med et andet firma, som ikke har samme renommé som Decca, og Decca så måske kommer på fødderne igen om nogle år ... min sans for loyalitet og trofasthed ville ikke have det så godt med det. Hellere vente på, at Decca skal komme op igen.

- Kunne andre Carl Nielsenvarker end symfonierne og koncerterne komme på tale? Jeg tanker isar på Hymnus amoris, Sovnen og Tre Motetter. AfBrahms har du jo allerede indspillet kormusik her, hvad med en Nielsen-korplade?

- Jeg ville gerne gøre det, men jeg kan ikke se nogle umiddelbare muligheder for det. I givet fald skulle det være med MDR-koret, og der er et temmelig spændt forhold imellem MDR og Gewandhaus. På MDR er de meget ambitiøse og vil gerne bygge deres orkester op, og det er også vigtigt, det skal de gøre, det har de brug for, men de ser ethvert samarbejde med Gewandhaus som en slags risiko, de vil hellere profilere sig selv. Tidligere anvendte Gewandhaus næsten altid MDR-koret til større hovedopgaver, men nu vægrer de sig ved at stille med koret, som er mægtig godt, som er et stort kor, der prøver flere timer om dagen, og som er det fineste MDR har. For tiden er det deres politik, at når MDR-koret optræder, skal det være med deres eget orkester, for på den måde kan de understøtte og give deres eget orkester et løft. Jeg synes de overdriver det, og på langt sigt mener jeg også, det er forkert, men på kort sigt kan jeg forstå dem. Så lige nu tror jeg ikke, der er udsigt til en korplade, men vi har påbegyndt en opbygning af vort eget kor med en dansk dirigent, Morten Schuldt-Jensen, og når det begynder at bære frugt, så ligger det måske lidt anderledes.

$$
\text { - Jeg kan ikke undlade at tale lidt }
$$
for operaen Saulog David også. Jeg har altid ment, at det maitte vare varket for dig, både pa 
grund af det bibelske tema og fordi operaen $i$

sin form bade narmer sig symfonien og

oratoriet. Carl Nielsens forhold til opera var jo

alt andet end traditionelt.

- Jeg vil forfærdelig gerne gøre

det, jeg beundrer værket, og jeg husker

meget godt opførelsen i København med

Horenstein. Men det er også en enorm

opgave, jeg tøver lidt. Opgaven som

Gewandhauskapellmeister er utrolig

omfattende. Nu sidder vi her, det er snart

midnat, og sådan er det faktisk hver dag.

Der er så mange, som kommer fra nær og fjern, og alting er vigtigt, og alting er interessant. Det er en voldsom kamp om tiden, og skulle jeg tage mig af en Saul og David, som jeg aldrig før har opført, så skulle jeg tage fri fra Gewandhaus et halvt år, og så længe kan jeg ikke forlade dem, ... siger manden, der i andre erhverv allerede ville have været pensioneret, med sin drengede latter.

(Interviwet med Herbert Blomstedt fortsætter i næste nummer af Magasin)

(C) John Fellow, december 1999 